УДК 338.2:658.15

DOI: https://doi.org/10.37320/2415-3583/13.4

Гордіснко Н.I.

кандидат економічних наук, професор,

Харківський національний університет міського господарства імені О.М. Бекетова

Ілляшенко О.В.

доктор економічних наук, професор,

Харківський національний університет міського господарства імені О.М. Бекетова

Литовченко О.Ю.

кандидат економічних наук, доцент, Харківський національний університет міського господарства імені О.М. Бекетова

\title{
ОРГАНІЗАЦІЯ ТА ОБЛІКОВО-АНАЛІТИЧНЕ ЗАБЕЗПЕЧЕННЯ УПРАВЛІННЯ РЕЗУЛЬТАТИВНІСТЮ ДІЯЛЬНОСТІ ПІДПРИЕМСТВА
}

У статті розглянуто організацію та обліково-аналітичне забезпечення системи антикризового управління результативністю діяльності корпоративного підприємства. Доведено актуальність вартісно-орієнтованого підходу до формування достовірної оцінки наявних можливостей підприємства та залучення потенційних інвесторів. Запропоновано організаційно-інформачійну схему, яка визначає інформаційні канали та систему комунікацій шляхом введення у традиційний порядок корпоративного управління прогнозних розрахунків показників результативності, яка, на відміну від наявних, створює вартісно-орієнтовану інформаційно-комунікативну мережу зв'язків, охоплює інформаційні потоки зовнішнього й внутрішнього середовища та сприяє формуванню реальних планових бюджетів, спрямованих на зростання вартості підприємства.

Ключові слова: підприємство, корпоративне управління, організаційно-інформачійне забезпечення, обліковоаналітичне забезпечення, планові бюджети.

Постановка проблеми. В обставинах світової фінансової кризи особливої актуальності набула проблема вдосконалення корпоративного управлення діяльністю підприємства. 3 огляду на це значущість та актуальність питань, які вимагають вирішення та відповідають рівню господарського розвитку підприємств, обумовлюють необхідність вдосконалення процесу обліково-аналітичного та організаційно-інформаційного забезпечення корпоративного управління результативністю діяльності підприємства.

В цьому аспекті актуальними стають питання визначення критеріїв оцінювання результативності діяльності корпоративних підприємств; формування системи показників для діагностики складових частин результативності за видами діяльності; адаптування сучасних зарубіжних методів і моделей управління результативністю до умов України та організації і обліково-аналітичного забезпечення управління результативністю.

Аналіз останніх досліджень і публікацій. 3 огляду на актуальність проблеми підвищення результативності діяльності підприємств через підвищення його вартості набули поширення вартісноорієнтований підхід до управління результативністю та моделі, засновані на управлінні вартістю, дослідженню яких присвячені наукові праці відомих економістів, таких як А. Дамодаран, Т. Коупленд, А. Мендрул, Дж. Рош, Дж. Стерн, Б. Стюарт, У. Шарп, Дж. Фрідмен [1-6]. Використання цього підходу сприяло появі у вітчизняній економічній літературі механізмів та методик управління діяльністю корпоративних підприємств, спрямованих на застосування зарубіжного досвіду у вітчизняній практиці. Проте багато питань організації та обліково-аналітичного забезпечення управління вартістю підприємства потребують подальшого розвитку.

Мета статті полягає у розробленні організаційноінформаційної моделі корпоративного управління вартістю підприємства та обліково-аналітичного забезпечення іiі реалізації.

Виклад основного матеріалу. Антикризовий механізм управління результативністю діяльності акціонерних товариств будівельної галузі грунтується на таких концептуальних положеннях і принципах: концепція ЕБМ, тобто менеджменту на основі очікувань, призначена для порівняння фактичних досягнутих результатів з очікуваннями власників та інших зацікавлених осіб, це система взаємопов'язаних та погоджених способів визначення результативності та управління результативністю [2]; концепція вартісно-орієнтованого управління (VBM) - це підхід менеджменту, що забезпечує послідовне управління вартістю акціонерного товариства (максимізація акціонерної вартості) [7-10].

Базуючись на застосуванні вартісно-орієнтованого підходу до управління результативністю, відповідно до цілей та очікувань зацікавлених осіб, ми вибрали критерій, виходячи із загальної мети діяльності підприємства, яка об’єднує суспільну мету, що проявляється у необхідності задовольнити потреби суспільства в продукції, та мету для власників, спрямовану на максимізацію їхнього добробуту за рахунок зростання ринкової вартості акцій товариства, а також отримання дивідендів. Як критерій результативності використано індикатор вартості, який інтегрує результативність операційної, інвестиційної та фінансової діяльності й визначається на базі складових частин формули EVA як співвідношення скоригованого чистого прибутку та середньозваженої вартості капіталу [11-14]. 
Впровадження системи корпоративного управління діяльністю підприємства в національну практику потребує ретельної підготовчої роботи адміністративного та управлінського персоналу, яка складається з аналізу зовнішнього середовища, що включає аналіз політичної ситуації для планування обмежень, які призводять до скорочування можливостей розширення розмірів підприємства; загальних економічних умов, що призводять до скорочення обсягів виробництва; державного регулювання у сфері зайнятості населення; результатів досліджень ринку будівельної продукції; екологічних вимог, що впливають на галузь; вимог нормативних правових актів, які регулюють сферу діяльності; правових та інших зовнішніх факторів, що впливають на діяльність, включаючи застосовувані принципи й методи ведення бухгалтерського обліку та підготовки фінансової (бухгалтерської) звітності; аналізу внутрішнього середовища, що включає аналіз стратегічних завдань виробничої діяльності й методи їхньої реалізації; характер діяльності, який визначається формою власності й способом управління, видами фінансових вкладень, що здійснюються, їхньою структурою й джерелами фінансування.

На основі моделі управління вартістю розроблено організаційно-інформаційну схему управління результативністю діяльності підприємства (рис. 1), яка включає аналіз поточної діяльності підприємства, що проводиться за такими напрямами.

1) У сфері операційної діяльності проводиться аналіз ринків збуту та частки ринку, що займає продукція підприємства; основних покупців і замовників щодо довгострокових контрактів; важливих постачальників щодо стабільності поставок та способів поставки; умов розрахунків за продукцію; основних конкурентів; цінової політики; методів виробництва; географічних та операційних сегментів діяльності; видів кооперації; маркетингової діяльності; персоналу, що включає рівень заробітної плати, адміністративні витрати, особливості соціального забезпечення, заохочувальні виплати, право на пільгове придбання акцій свого підприємства; необхідності підвищення кваліфікації; кадрової політики; витрат на науково-дослідні й дослідно-конструкторські роботи.

2) У сфері інвестиційної діяльності проводиться аналіз намірів продажу частини активів, придбання, злиття, ліквідації окремих сегментів діяльності; придбання цінних паперів, капіталовкладень, включаючи придбання будинків та іншої нерухомості, устаткування, технологій; інвестицій у спільну діяльність; оренди нерухомості або устаткування; використання похідних фінансових інструментів.

3) У сфері фінансової діяльності проводиться аналіз змін у структурі капіталу; залучення банківських кредитів; стану розрахунків та погашення кредитів, відсотків; прибутку або збитку в результаті коливання валютних курсів; складу боргів, забезпечення зобов'язань, виданих гарантій.

4) У сфері управління діяльністю підприємства проводиться аналіз інформаційних систем, що відповідають цілям організації; наявних систем контролю за одержанням зовнішньої та внутрішньої інформації, що забезпечує надання відповідних звітів керівництву; комунікацій щодо наявності формалізованих планів розвитку й бізнес-планів, що реалізуються на практиці; розгляду планів та їхнього регулювання шляхом урахування можливостей і наслідків.

Фінансовий відділ узагальнює результати аналізу зовнішнього й внутрішнього середовища та подає інформацію до вищого виконавчого органу підприємства.

До компетенції наглядової ради акціонерного товариства входять обов'язки регулювання діяльності вищого виконавчого органу, затвердження питань, пов'язаних 3 його діяльністю та ринковою вартістю майна. У зв'язку з тим, що оцінювання майна акціонерного товариства проводиться відповідно до законодавства про оцінювання майна, майнових прав та професійну оціночну діяльність, а також частин першої, другої і третьої статті 8 Закону України «Про акціонерні товариства» [15], важливими $€$ визначення ринкової вартості та управління нею в поточній діяльності підприємства задля підвищення добробуту акціонерів та його інвестиційної привабливості.

Очікування акціонерів на підвищення вартості підприємства та виплати дивідендів визначаються через корпоративного секретаря, який здійснює взаємодію акціонерів та акціонерного товариства шляхом проведення та аналізу анкетування, результати якого надходять до наглядової ради.

Служба внутрішнього аудиту, окрім питань, що передаються ій для вивчення, узагальнює результати аналізу зовнішнього та внутрішнього середовища, проведеного фінансовим відділом, визначає показники результативності, які відповідають обгрунтованим очікуванням акціонерів, а також інформує наглядову раду. Після узгодження очікуваних показників результативності наглядова рада передає інформацію до вищого виконавчого органу акціонерного товариства.

Задля формування бази даних і прогнозування показників діяльності вищий виконавчий орган дає розпорядження відділам апарату управління про збирання відповідної інформації, що базується на фінансовій, статистичній звітності та аналітичних даних, а також передається до фінансового відділу.

Фінансовий відділ проводить розрахунок прогнозних показників результативності на підставі економіко-математичної моделі, виявляє розбіжності між прогнозними та очікуваними показниками результативності.

Виявлені розбіжності між прогнозними та очікуваними показниками аналізуються планово-економічним відділом задля розроблення завдань іншим підрозділам апарату управління для формування відповідних організаційно-технічних, технологічних та фінансових заходів. Ці заходи узагальнюються, формується загальна система заходів, спрямованих на зростання результативності діяльності, з урахуванням якої формується річний прогнозний бюджет підприємства.

Прогнозні значення основних (бюджетних) показників є підсумковими, вони служать орієнтиром під час формування відповідних планових бюджетів. Прогнозні базові показники їх доповнюють шляхом встановлення певних обмежень і співвідношень, які враховують особливості діяльності, технічні та фінансові можливості підприємства, що втілюються через відповідні організаційно-технічні та фінансові заходи, спрямовані на досягнення очікуваних результатів. Прогнозний бюджет підприємства передається вищому управлінському персоналу для затвердження. 


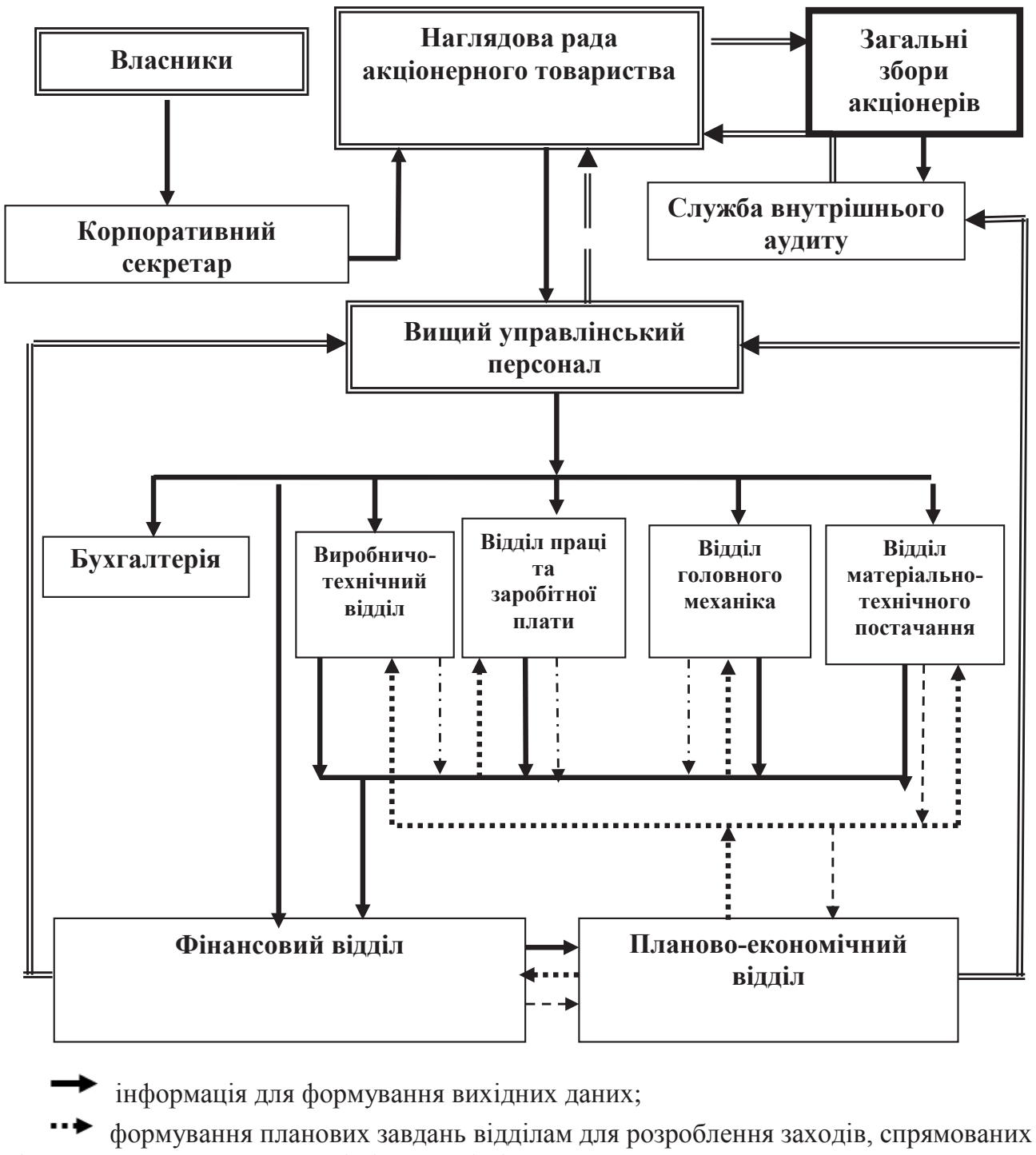

на підвищення результативності діяльності підприємства;

- -> формування відділами комплексу заходів, що забезпечать зростання

результативності діяльності підприємства;

$\Rightarrow$ інформація про результати моніторингу виконання планових бюджетів

\section{Рисунок 1 - Організаційно-інформаційна схема системи антикризового управління} результативністю діяльності підприємства

Плановий відділ проводить щоквартальний моніторинг виконання планових бюджетів, результати моніторингу подаються вищому управлінському персоналу та службі внутрішнього аудиту для аналізу та прийняття рішення про необхідність їхнього корегування.

У разі прийняття рішення про корегування планових бюджетів плановим відділом проводиться корегування системи організаційно-технічних, технологічних і фінансових заходів та показників планового бюджету. Скореговані планові бюджети вищий виконавчий орган акціонерного товариства передає до наглядової ради для формування звіту на загальних зборах акціонерів та затвердження бюджету на плановий рік.

На основі скорегованих прогнозних значень показників формуються комплекс прогнозних бюджетів підприємства та зведений плановий бюджет на рік.
До комплексу прогнозних бюджетів входять бюджет амортизації, бюджет витрат на сировину та матеріали, бюджет витрат на оплату праці, бюджет адміністративних витрат, бюджет витрат на збут, бюджет собівартості продукції, бюджет інвестицій, бюджет коштів та формування кредитного плану.

Висновки. Таким чином, реалізація моделі, призначеної для корпоративного управління діяльністю підприємства, дає змогу визначати основні показники планових бюджетів, які враховують очікувані (бажані) темпи зростання вартості підприємства та ресурсні можливості їхнього досягнення. Наведена організаційно-інформаційна схема конкретизує відповідні функції та завдання підрозділів апарату управління, визначає інформаційні канали та відповідну систему комунікацій у процесі корпоративного управління діяльністю підприємства. 


\section{Список використаних джерел:}

1. Дамодаран А. Инвестиционная оценка: инструменты и методы оценки любых активов / пер. с англ. Д. Липинский, И. Розмаинский. 2-е изд. Москва, 2005. 1341 с.

2. Коупленд Т. Аарон Долгофф Expectations - Based Management: как достичь превосходства в управлении стоимостью компании / пер. с англ. Э. Кондуковой. Москва, 2009. 384 с.

3. Мендрул О. Управління вартістю підприємств : монографія. Київ, 2002. 272 с.

4. Рош Дж. Стоимость компании: от ожидаемого к действительному / пер. с англ. Е. Недбальской. Минск, 2008. 352 с.

5. Шарп У.Ф., Александер Дж., Бейли Дж. Инвестиции / пер. с англ. В. Ковалев. Москва, 1997. 1127 с.

6. Фридмен Д., Ордуэй Н. Анализ и оценка приносящей доход недвижимости. Москва, 1995. 462 с.

7. Stewart G.B., Bonnelt G. EVA: Fact and Fantasy. Journal of Applied Corporate Finance. 1994. Vol. 7. No. 2. P. $71-87$.

8. Stern S. The Comparative Stock Market Performance. 2005. URL: www.sternstewart.com/evaabout/eva_works.php

9. Miller M.H. Franco Modigliani. Dividend Policy Growth, and the Valution of Shares. Journal of Business. 1961. Vol. 34.

No. 4. P. 411-433.

10. Worthington A., West T. Economic Value-Added: a Review of the Theoretical and Empirical Literature. Asian Review of Accounting. 2001. Vol. 9. No. 1. P. 67-86.

11. Момот Т., Гордієнко Т. Адаптація критичної концепції економічної доданої вартості (ЕVA) до економіки України. Коммунальное хозяйство городов. 2008. Вып. 77. С. 39-41.

12. Гордієнко Н., Гордієнко Т. Методичне забезпечення антикризового механізму управління результативністю діяльності акціонерних товариств будівельної галузі. Теоретичні і прикладні аспекти підвищення конкурентоспроможності підприсмств : колективна монографія : у 4 т. / за ред. О.А. Паршиної. Дніпропетровськ, 2013. Т. 3. С. 80-86.

13. Gordiyenko N., Gordiyenko T. Adaptation of the value management concept to the national practice of the entity's activity. Topical questions of contemporary science : collection of scientific articles. Aspect Publishing of Budget Printing Center, Taunton, MA 02780, United States of America, 2017. P. 118-125.

14. Гордієнко Н., Азарова Т. Особливості оцінки та забезпечення економічної безпеки підприємств будівельної галузі. Проблеми системного підходу в економіuі. 2019. Вип. 2(70). Ч. 1. С. 87-93. URL: www.psae-jrnl.nau.in.ua

15. Про акціонерні товариства : Закон України від 17 вересня 2008 р. № 514-VI, із змінами до Закону від 3 лютого 2011 р. № 2994-VI. Відомості Верховної Ради Украӥни. 2011. № 35. Ст. 344.

\section{References:}

1. Damodaran A. (2005). Ynvestytsyonnaia otsenka: ynstrumenty y metody otsenky liubykh aktyvov [Investment appraisal: tools and methods for appraising any assets] / per. from English. D. Lipinsky, I. Rozminsky. 2nd ed. Moscow: Alpina Basis Boxing, 1341 p. (in Russian)

2. Kouplend T. Aaron Dolhoff (2009). Expectations - Based Management: kak dostych prevoskhodstva v upravlenyy stoymostiu kompanyy [How to achieve excellence in company value management ] / per. from English. E. Kondukova. Moscow: ESMO, 384 p. (in Russian)

3. Mendrul O. (2002). Upravlinnia vartistiu pidpryiemstv: monohorafiia [Management of business enterprises]. Kyiv: KNU, 272 p. (in Ukrainian)

4. Rosh Dzh. (2008). Stoymost kompanyy: ot ozhydaemoho k deistvytelnomu [Company value: from expected to actual] / per. from English. E. I. Nedbalskoy. Minsk: Grivtsov Publisher, 352 p. (Belarus)

5. Sharp U.F., Aleksander Dzh., Beily Dzh. (1997). Ynvestytsyy [Investments ] / per. from English. V. Kovalev. Moscow: INFRA-M. Delo LTD, 1127 p. (in Russian)

6. Frydmen D., Orduei N. (1995). Analyz y otsenka prynosiashchei dokhod nedvyzhymosty [Analysis and valuation of income-generating real estate]. Moscow, 462 p. (in Russian)

7. Stewart G.B. (1994). EVA: Fact and Fantasy / G.B. Stewart, G. Bonnelt. Journal of Applied Corporate Finance, vol. 7, no. 2, p. $71-87$.

8. Stern Stewart (2005). The Comparative Stock Market Performance of Stern Stewart Clients. URL: www.sternstewart.com/ evaabout/eva_works.php

9. Miller M.H. Franco Modigliani (1961). Dividend Policy Growth, and the Valution of Shares. Jornal of Business, vol. 34, no. 4, pp. 411-433.

10. Worthington A. (2001). Economic Value-Added: a Review of the Theoretical and Empirical Literature / A. Worthington, T. West Asian Review of Accounting, vol. 9, no. 1, pp. 67-86.

11. Momot T., Hordiienko T. (2008). Adaptatsiia krytychnoi kontseptsii ekonomichnoi dodanoi vartosti (EVA) do ekonomiky Ukrainy [Adaptation of the critical concept of economic value added (EVA) to the economy of Ukraine]. Kommunalnoe khoziaistvo horodov, vyp. 77, pp. 39-41.

12. Hordiienko N., Hordiienko T. (2013). Metodychne zabezpechennia antykryzovoho mekhanizmu upravlinnia rezultatyvnistiu diialnosti aktsionernykh tovarystv budivelnoi haluzi [Theoretical and applied aspects of advancing the competitiveness of enterprises: a collective monograph] in 4 volumes / edited by O. Parshina. Dnipropetrovsk: Gerda, vol. 3, pp. 80-86.

13. Gordiyenko N., Gordiyenko T. (2017). Adaptation of the value management concept to the national practice of the entitys activity .Topical questions of contemporary science: Collection of scientific articles. Aspekt Publishing of Budget Printing Center, Taunton, MA 02780, United States of America, pp. 118-125.

14. Hordiienko N., Azarova T. (2019). Osoblyvosti otsinky ta zabezpechennia ekonomichnoi bezpeky pidpryiemstv budivelnoi haluzi [Features of assessment and economic security of enterprises in the construction industry]. Problems of systemic approach to economy, vyp. 2(70), ch. 1, pp. 87-93. URL: www.psae-jrnl.nau.in.ua

15. Pro aktsionerni tovarystva : Zakon Ukrainy vid 17 veresnya 2008 r. № 514-VI, iz zminamy do zakonu vid 03 liutogo $2011 \mathrm{r}$. № 2994-VI. Vidomosti Verkhovnoi Rady Ukrainy. 2011. № 35. St. 344. 
Gordiyenko Natalia, Illiashenko Olena, Lytovchenko Olena

O.M. Beketov National University of Urban Economy in Kharkiv

\section{ORGANIZATION AND ACCOUNTING-ANALYTICAL SUPPORT OF THE ENTERPRISE'S EFFICIENCY MANAGEMENT}

Orientation of the corporate management system on increasing its value requires improvement and implementation of effective anti-crisis management mechanisms based on modern methods, primarily a value-based approach to form a reliable assessment of existing opportunities and attract potential investors. The value of the enterprise is the result of its activities and a sign of improving the welfare of owners. The variety of theoretical and methodological approaches and ambiguity of interpretations in the economic literature of the enterprise's market value essence in theoretical, legislative and practical aspects is proof of the complexity of this economic category, the interpretation of which should be approached depending on the purpose and scope. In view of the above, the urgency of the issues that need to be addressed necessitates the improvement of the process of accounting-analytical and organizational-information support of corporate performance management. For implementation the anti-crisis managing mechanism of the corporate enterprise effectiveness on the basis of cost-oriented management and management based on expectations, a holistic set of interrelated organizational and informational actions is proposed, which allows to quickly identify trends of the enterprise's value change, contributes to make informed management decisions aimed at eliminating negative trends of the development, the objectives of the activity by applying the tools of value-based corporate management and activities aimed at maximizing the welfare of owners and harmonization of corporate relations. Diagnostic instrument used for the calculation of determining the enterprise value is the indicator, which, unlike the known model of economic value added (EVA), calculated as the ratio of net adjusted income and the weighted average cost of capital adapted to national financial reporting information data. The proposed indicator allows for a direct response, including corporate action to prevent a decline in the market value of shares. An organizational and information scheme is proposed, which specifies the tasks of the enterprise managements, defines information channels and communication system by introducing into the traditional order of corporate management and short term planning forecast calculations of performance indicators. The proposed organizational and information scheme, in contrast to the existing ones, creates a value-based information and communication network, covers the information flows of the external and internal environment, promotes the formation of real planned budgets aimed at increasing the value of the enterprise.

Key words: enterprise, corporate management, organizational and information support, accounting and analytical support, planned budgets.

JEL classification: L25, M11, M21, M41 